\title{
How Cnidaria Got Its Cnidocysts
}

\section{Stanley Shostak}

Department of Biological Sciences, University of Pittsburgh, USA

*Corresponding author: Stanley Shostak, Department of Biological Sciences, University of Pittsburgh, USA, Tel: 0114129156595, E-mail: sshostak@pitt.edu

Received date: May 06, 2015; Accepted date: Aug 03, 2015; Published date: Aug 11, 2015

Copyright: () 2015 Shostak S. This is an open-access article distributed under the terms of the Creative Commons Attribution License, which permits unrestricted use, distribution, and reproduction in any medium, provided the original author and source are credited.

\begin{abstract}
A complex hypothesis is offered for the origins of cnidarian cnidocysts through symbiogeny. The two-part hypothetical pathway links the origins of tissues through an early amalgamation of amoebic and epithelial cells to and the later introduction of an extrusion apparatus from bacterial parasites. The first part of the hypothesis is based on evidence for morphological, molecular, and developmental similarities of cnidarians and myxozoans indicative of common ancestry. Support is drawn from Ediacaran fossils suggesting that stem-metazoans consisted of symbiogenic pairs of epithelial-like shells enclosing amoeba-like cells. The amoeba-like cells would have evolved into germ cells and cells differentiating as or inducing nerve, muscle, and gland cells. The second part of the hypothesis proposes that cnidocysts evolved in a cnidarian/myxozoan branch of the metazoan tree through the horizontal transfer of bacterial genes encoding an extrusion apparatus to proto-cnidarian amoebic cells and consequently to the Cnidarian germ line. Evidence for bacterial genes in Cnidaria and transposable elements are cited in support of this part of the hypothesis.
\end{abstract}

Keywords: Cnidaria; Cnidocysts; Epithelial cells

\section{Introduction}

Ever since the modern synthesis, efforts to sort out the source(s) of unique phylogenic characteristics start with the assumption of de novo novelty: "mutation did it." Symbiosis offers an alternative source of cladogenic innovation albeit requiring compounding hypotheses with horizontal gene transfer. Setting aside this complication, the origins of cnidocysts in Cnidaria offers a unique opportunity for examining a hypothetical role for symbiosis in metazoan evolution.

Nowadays, macro- and micro-cnidarians are identified by the presence of cnidocysts (also known as nematocysts in Cnidaria and polar capsules in Myxozoa). Otherwise, cnidarians per se would seem to have little in common. Macro-cnidarians are classical anthozoans (anemones and corals) and medusozoans (medusas [jellyfish] and polyps), while micro-cnidarians are myxozoans, comprising myxosporean (including actinosporeans) and malacosporean parasites. The question is, "How did cnidarians of either size acquire similar cnidocysts?"

Richard Christen et al. [1] offered an answer: "the unorthodox possibility that... metazoans (and possibly plants) were the results not of the aggregation of a single species of unicellular organisms, but the results of various symbiotic events between different types of protistan organisms." In the early 1990s, several eukaryotic protistans had already been nominated as candidates for sources of cnidocyst, but the notion of "symbiotic events" was only beginning to be taken seriously as a driving force of evolution [2,3].

Morphological similarities had long been recognized between cnidarian cnidocysts, and microbial "cnidocysts" $[4,5]$, specifically the "peduncle," "rhizoid," and "perforator" of dinoflagellates [6-8], the trichocysts of trypanosomes [9], zooflagellates [10] and mastigophorans [11], the "apicoplasts" (apical complexes) of "Sporozoa," the "polaroplast," of microsporidian [12], and the "polar capsules" of myxosporidians [13-19]. Taking these similarities into account, Jiři Lom noted "homologies [were] perhaps too close to be considered only a convergency phenomenon" [20], and Pierre Tardent commented "The wheel didn't have to reinvent itself" [21].

Thus, I suggested that "any of several or even more than one 'sporozoan' or predatory dinoflagellate... [might have served as] the source of cnidarian cnidocysts" [22], and Leo Buss and Adolf Seilacher famously "hypothesize[d] the existence of a cnidarian ancestor that lacked cnidae" and was subsequently parasitized by a microsporidian bearing an extrusion apparatus. This "parasitism ultimately led to the integration of genes required for polar capsule syntheses into the cnidarian ancestor's genome" [23]. Likewise, Jason Holland et al. alluded to the possibility that "nematocysts did not originate in cnidarians... [but] could be explained by lateral organelle or gene transfer from protists that possess extrusible organelles similar to nematocysts [16]. These hypotheses, whether invoking sporozoans, microsporidians, or simply protists as the source of cnidocytes had fatal weaknesses, however, and alternatives were necessary to overcome these weaknesses.

\section{Fatal Weaknesses}

Buss and Seilacher's [23] choice of microsporidians as the parasitic source of cnidocysts was perfectly reasonable especially, since at the time, microsporidians and myxospreans were considered closely related: They both lacked flagella, and had an extrusible organ, the polaroplast or polar capsule, respectively. The conspicuous cnidarian "penetrant" or stenotele resembled the microsporidian polaroplast's "spore extrusion apparatus (EXA)... equipped to explosively discharge a tube through which the infective sporoplasm is sent into a host cell" [24], while the sticky or ensnaring tube of most cnidarian cnidocytes more nearly resembled the thread averted by myxosporean's polar capsules.

Differences in the cellularity of microsporidians and of cnidarians suggested that the similarities between polaroplasts and cnidocysts 
were due to convergence, however. Eventually, "profound differences in biology and ultrastructure were demonstrated" [25], and Microsporidia fell out of the running for ancestor of cnidarian cnidocysts.

Myxosporidians were also eliminated as the sources of cnidarian cnidocysts, but their fatal flaw was not the failure of homologies. Rather, their problem was one of timing: Which came first?

Historically, metazoan characteristics were recognized in cells or plasmodia formed during myxozoans' parasitic life cycles, for example, the metazoan-like separation of somatic cells (with diploid nuclei, tight junctions, and collagen) from germ cells (with haploid nuclei and intercellular bridges). But the place of myxozoans in the Metazoa was shrouded in ambiguity. For example, Polypodium hydriforme, the infamous parasite of caviar bore Cnidarian-like cnidocyst, while, Buddenbrockia plumatellae, the parasitic "worm" of freshwater bryozoans was thought to be a myxozoan. Ultimately, arguments on behalf of Polypodium's place among the cnidarians (Narcomedusae [18]) were strengthened with molecular evidence [19] and Polypodium was established as a parasitic cnidarian that lives as an inverted stolon (gastrodermis facing the yolk) within sturgeons' ovarian eggs. Upon oviposition, stolons escape, and buds evaginate. The resulting polyps, equipped with cnidocysts, form gonads containing (presumably) infectious germ cells (analogous [homologous?] to myxozoan spores. Likewise, molecular affinities were discovered between the "cnidarian" Buddenbrockia plumatellae and the malacosporean Tetracapsuloides bryozoides [14,19,26-28]. Thus, the knot tying Myxozoa to Cnidaria continued to tighten.

Microscopic evidence also supported the homology of myxozoan polar capsules and cnidarian cnidocysts. Cnidocysts had long been recognized as intra-cellular "organoids" [29] or encapsulated cellular organelles. Ultrastructurally, cnidarian cnidoblasts (aka nematoblasts) produce cnidocysts within an enlarged golgi apparatus [30], and myxozoans' capsulogenic cells produce polar capsules within the golgi apparatus (from vesicles arising in the rough endoplasmic reticulum [20]). Furthermore, "both myxozoan polar capsules and cnidarian nematocysts consist of a capsule whose wall is continuous with a coiled tubule that everts from its apical end" [31].

Since the most fundamental evidence of homology is molecular, the discovery of "nematocyst" proteins (nematogalectins and minicollagens) shared by cnidarian cnidocysts and myxozoan polar capsules [17, reviewed 25] clinched the case for the homology [13-20,26-28,31]. Consequently, Myxozoa was moved out of Protista [32], into the Metazoa [33], and the "demise" of the protozoan class of myxozoans was declared $[34,35]$.

Nevertheless, myxozoans could not have been the source of cnidarian cnidocysts! Sequence comparisons of complete small subunit ribosomal RNA coding regions demonstrate that "myxozoans emerged after the cnidarians, and thus could not give rise to a cnidarian endobiont that eventually might have evolved into the nematocyst" [15, emphasis added]. In other words, homologies notwithstanding, cnidarians came first! Myxozoan polar capsules arose from cnidarian cnidocysts and not vice versa.

\section{Status of the Myxozoa/Cnidaria Relationship}

Myxozoa does not sit comfortably on the metazoan tree. "The unexpected diversity in the genomic organization" [36] presented difficulties for ascertaining where the myxozoans resided among metazoans. Ambiguity surrounded comparative analyses of HOX gene clusters [37,38] and small subunit ribosomal RNA (SSU rRNA), 18S and 16S ribosomal RNA (rDNA) and 5S and 5.8S rRNA [15,39-41]. Conflicting evidence pointed toward a closer relationship of microbial eukaryotes with Bilateria (metazoans excluding Porifera, Cnidaria, Ctenophora, and Placazoa $[15,19,42,43]$ ) or with Radiata (aka. Coelenterata: Cnidaria, Ctenophora, and Placazoa) [14,16-18]. This conflict may be resolved, however, were Cnidaria reassigned to the Bilateria (not unjustified morphologically given some anemones' mirror-image symmetry around the mid-sagittal plane).

Presently, Myxozoa has two classes, Myxosporea and Malacosporea (comprising Tetracapsuloides and Buddenbrockia [44]) (The previous classes, Myxosporea and Actinosporea [20], are probably "alternating life stages of a single organism" [13]). Myxozoa, as such, constitutes an "unranked subphylum" within Cnidaria [45], a "sister to Medusozoa within Cnidaria" [31], or a class "within the phylum Cnidaria, on the medusozoan lineage" [27]. Placement is yet to be made and the question remains open whether "myxozoans are highly degenerate cnidarians" [17] or extreme members of a parasitic branch of Cnidaria $[18,46,47]$.

\section{Comparative morphology}

Robert Weill [4] drew attention to the protist/cnidarian comparison while describing seventeen recognizable cnidocysts (now nearly thirty morphological types or as few as four proteomic types [based on minicollagen genes]). Different types of cnidocyst [5-8] are adapted to different functions from procuring prey, defence, aiding digestion, and (if rarely) supporting structure. The averted tube may deliver a dose of venom, ensnaring glue, promote mixing currents, or reinforce the wall of burrows [48-53].

In as much as "it is very dangerous at present to lay too much stress on the value of nematocysts, pending a thorough investigation of variability and occurrence" [54], cnidocyst morphology has played a limited role in cnidarian taxonomy. Even the identity of particular cnidocysts may be uncertain. For example, the atrichous isorhizers (a-: without; trich: spines; iso-: same; rhiza: tube: a uniformly slender tube without prominent spines) are considered primitive and typical of octocorallian anthozoans [55], although the basitrichs (basi: base: tube with spines at base) is also said to be "the single type of nematocyst... in the Octocorallia" [56]. Additional types of cnidocysts found in Hexacorallia suggest that the acquisition of cnidocysts with a slender thread and a cylindrical "butt," (the whip bearing "mastigophore-type" [29]) may have preceded hexacorallian diversification [57].

Atrichous isorhizas are also present in the Medusozoa (Staurozoa, Scyphozoa, Hydrozoa, and Cubozoa). Their presence in both cnidarian subphyla (Anthozoa and Medusozoa) recommends them as originary, although holotrichous isorhizas (holo-: uniform), present throughout the Hexacorallia, are rarely present in the Medusazoa. Both cnidarian subphyla harbor a family of cnidocysts consisting of varieties of isorhizas and mastogophores, but Filifera and Capitata (Anthoathecata, Hydrozoa) alone harbor a second family consisting of microbasic euryteles (eury-: broad; tele: end: tube dilated at end of butt [rare in thecate hydrozoans]) and desmonemes (desmos- bond; nema: thread: binding thread) or volvents (volvere: to turn or twist: thick tube forming an ensnaring corkscrew at discharge), while stenoteles (steno: short) or penetrants (butt of tube with small spines in spiral pattern, "thorns" and long slender basal "stylets") occur (almost) exclusively in the Capitate hydrozoans [57,58]. Among anthozoans, hexacorallians uniquely harbor spirocysts (may not be homologous to other 
cnidocysts [59]) and ptychocysts (in cerianthidans [49]), Thus, while some common cnidocysts presumably evolved from a few originary varieties, other cnidocysts seem to have been acquired separately in anthozoans and medusozoans [57].

In contrast to the variety of cnidarian cnidocysts, the polar capsules of myxozoans are not conspicuously different, although Jiři Lom attempted to draw attention to polar capsule morphology for the purpose of Myxozoa taxonomy [20,60,61]. Polar capsules contain the coiled polar tubule that everts typically as a fine closed tube (with the exception of Sphaeromya) continuous with the polar capsular wall. The averted polar tube is "sticky" and may attach to and anchor the spore to host tissue. Presumably, the infectious sporoplasms (amoebula, planont, or sporozoite) are guided by the tubule to the host target.

Lom proposed that "genera with unicapsular spores... originated from bicapsular ones" [20]. Other authorities defined orders (or suborders) by the number of valves and polar capsules in a spore and whether they were present in equal numbers as opposed to having twice as many valves as polar capsules [62]. The shape of spores, whether spherical, rectangular, stellate, or without a distinctly anterior surface also figured into taxonomy and assertions about natural phylogenetic relationships.

\section{Developmental biology}

Cnidarian cnidoblasts first appear among inner cells of embryos before the emergence of polarity. In embryos of the marine hydrozoan, Pennaria tiarella, "the inner cells will give rise to endoderm and interstitial cells, while the outer cells will form larval ectoderm" [63] consisting of epithelial and mucous (gland) cells. Soon thereafter, however, only a "few developing interstitial cells and nematoblasts are found in the central cores of the embryos" [63] and fewer still remain central when the mesoglea has formed and separated epidermis from gastrodermis. By 82 hours post-fertilization, interstitial cells (i.e., amoebic cells], nematoblasts (cnidoblasts), and ganglionic cells constitute thirty-one percent of the pre-metamorphic planula's outer cells. These cells have moved from the inner cell mass into the epidermis.

In polyps, amoebic cells are individual, small, densely basophilic, and with relatively large nuclei and nucleoli [64]. In hydra, these cells tend to populate interstices at the base of epidermal cells (hence, "interstitial cells"), while in other cnidarian polyps and in medusas, amoebic cells occupy the expanded inter-epithelial compartment as well.

Cnidoblasts (individually or in small clones) derived from amoebic cells or, in the anemone Nematostella vectensis from "cuboidal-shaped epithelial cells... detected both, in the ectodermal and entodermal tissue layers" [65] produce cnidocysts, migrate to tentacles (or other sites, such as the mesenterial filaments and acontia of anemones and gastrodermis of corals). Having once begun differentiating their cnidocyst, cnidoblasts settle into extracellular pockets. In the epidermis, cnidoblasts become cnidocytes when they form sheet-like fascial desmosome with specialized epidermal battery cells and become competent for discharging their cnidocyst. [30,43,50]. Epithelial cells provide "launch sites" and proximity to sensory and ganglionic cells that function in mechanism of cnidocyst discharge [66-69].

The amoebic cells of polyps and medusas are self-renewing [70] and the source of individual or small clones of cnidoblasts [71], but cells lack "myc, nanog, klf4, Oct4, and Sox2 genes that confer pluripotency on mammalian cells in culture" [72]. Thus, cnidarian amoebic cells do not correspond to embryonic stem cells (ESCs) or induced pluripotential stem cell (iPSCs) [73]. Rather, amoebic cells correspond to vertebrate adult stem cells (ASCs) with limited potential. Cnidoblasts, therefore, correspond to transitional amplifying cells (TACs) already differentiating along determined lines.

Epithelial cells have even more restricted competence. These cells have been shown numerous times to lack the potential to modulate into amoebic cells or any of their derivatives. For example, in hydra treated in any of a number of ways (colchicine, nitrogen mustard, hydroxyurea, urethane, or lowered temperature), interstitial cells are lost and with them germ, nerve, ganglionic, and gland cells $[74,75]$. When the loss is complete, the specialized cells do not regenerate, and behaviour suffers. The hydras do not move or eat, but if they are fed mechanically they grow, bud, and add supernumerary tentacles.

Similarly, Pennaria tiarella planulas treated with colchicine, podophyllotoxin, or vinblastine sulfate suffer the "complete elimination of interstitial cells, nematoblasts, and sensory-motor interneurons" [76]. In depleted planulas "the remaining cells... become organized into a distinct epidermis and gastrodermis separated by a mesoglea" albeit the successfully treated planulas die without metamorphosing into polyps [76].

If the missing amoebas are restored to hydras through grafting with normal head or foot tissue, the epithelial hydras re-acquire the missing specialized cells (germ, secretory, and, at least, some nerve cells [74,75], sperm [77] and egg [78]. The results with similarly grafted Pennaria planula are comparable except "reconstituted planular head pieces contain interstitial cells, ganglionic cells and a reforming neural plexus but few nematoblasts/nematocytes. Reconstituted planula tail pieces contained interstitial cells and nematoblast/nematocytes but no ganglionic cells" [79].

Myxosporidians have no definitive embryonic stage, but their sporogenic cells (sometimes called ova) are comparable to cnidarian amoebic cells by way of performing the role of adult stem cells and giving rise to cells of different types. For example, in Myxobolus, following a nuclear proliferative phase, multiple polyploid vegetative and diploid generative cells are carved out of a plasmodium. Generative cells pair and one cell becomes the sporogenic cell, while the other becomes a pericyte that envelopes the sporogenic cells. The pericyte divides and forms the pansporoblast, the mature spore's outermost envelope. The sporogenic cell divides meiotically to form valvogenic cells, the sporoplasmic sporoblast and capsulogenic cell.

In Aurantiactinomyxon, pansporoblast cells surround inner cells whose meiotic divisions produce gametes (shedding polar bodies in the process). Following fertilization (nuclear fusion), diploid sporoblasts organize into future sporoplasm, valvogenic, endospore, and capsulogenic cells. Early pansporoblasts contain eight primordial spore envelopes, each with a polar capsule connected to a primordial sporoplasm. Sporoplasmic masses coalesce with spore envelopes in mature spores as polar capsules differentiate in their capsulogenic cells.

Capsulogenic cells perform the function of cnidoblasts. Ultimately, the "structure of the polar capsules, and more importantly, of the capsulogenic cells, is exactly like that of the nematocysts in coelenterates" [i.e., the cnidocyst in Cnidaria] [20]. And like cnidoblasts, capsulogenic cells locate themselves strategically in the environment of shell valves aimed at a discharge canal in the pansporoblast. Although the launch mechanism is unknown, the polar tubule wends its way toward the host. 


\section{Origins of Cnidaria/Myxozoa}

Several fossils from the Precambrian, Ediacaran Doushantuo Formations have the appearance of myxospora in the form of cellular spheres enclosed in larger spheres. Specifically, phosphorite specimens from Weng-an, "in addition to the blastomere-like cells... [contain] one or more spheroidal to ellipsoidal multicellular structures, here termed matryoshkas in reference to their similarity to nested Russian dolls. The matryoshkas are of variable size $(30-350 \mu \mathrm{m})$ but they are generally larger than blastomere-like cells. They themselves are multicellular, consisting of tightly packed cells (9-14 $\mu \mathrm{m}$ in size) that are significantly smaller than the blastomere-like cells. Measurements show that the matryoshkas do not follow a palintonic cell division pattern... [Rather,] matryoshkas are growing structures, with cytoplasmic growth after each division to restore cell size" [80].

The similarity of matryoshkas to sporoplasm within sporoblasts is simply uncanny. Thus, the fossil record suggests that microscopic forms of cnidarians (as well as the macroscopic forms [81]) may have existed in the Ediacaran/Vendobionta.

This new image of Buss and Seilacher's cnidocyst-less ur-cnidarian [23] goes back to the Ediacara [82]. It is not a "choanoblastaea" [83], an aggregate of collar cells, but epithelial shell. The image is reminiscent of Placozoa [84], and suggests that placozoan-like forms might have constituted a common stem with cnidocyte-free cnidarians.

Represented today by Trichoplax adhaerens, Placozoa is "the most basal metazoan known... Genetic evidence also points to a position close to the last common metazoan ancestor" [85]. The placazoan's plate-like or compressed-sphere structure consists of epithelial-like layers (with marginal belt desmosomes but without adhering junctions or basal lamina) joined across an interspace by a vaguely connected (syncytial?) meshwork of stellate contractile fibre cells. The thin upper layer of flagellated cells contrasts with the thicker lower layer of cylindrical cells and non-flagellated gland cells. Stellate, contractile fibre cells are found in the interspace between the layers [86].

Despite its protean shape, Trichoplax is not bereft of the rudiments of symmetry. A "full coding region, spatial expression and function of Trox-2, the single Hox/ParaHox-type gene identified in Trichoplax... is expressed in a ring around the periphery of Trichoplax, in small cells located between the outer margins of the upper and lower epithelial cell layers. Inhibition of Trox-2 function, either by uptake of morpholino antisense oligonucleotides or by RNA interference, causes complete cessation of growth and binary fission" [86].

Under crowded conditions in the laboratory, Trichoplax is capable of producing egg (and sperm?), suggesting that germ cells arose in the ancestral animal. Oocytes are derived from ventral epithelium, but they are surrounded by a dense wicker-work of fibre cells that develops in the interspace. At the same time, large numbers of small nonflagellated round presumptive sperm appear in the interspace amidst fibre cells. In the laboratory, embryos are expelled from the degenerating "mother" at or before the 64-cell stage, although further development presumably occurs in the wild [87].

If the radial/bilaterian branch(es) of the metazoan tree exhibit a pattern of accumulation of amoeba-cells and diversification within epithelia-like shells, symbiogenetic integration [88] would seem to begin with amoebic cells in Trichoplax adhaerentes (however sparse and rudimentary) becoming competent for germ cell differentiation. The more abundant amoebic cells populating ctenophores induce nerve and give rise to muscle, as well as differentiate into germ cells.
Cnidaria exhibits an even greater accumulation of amoebic cells to the extent that, in contemporary hydrozoans, cnidocytes alone comprise almost half the cell population (e.g, estimates based on Hydra attenuata [89]) and along with germ cells, nerve, sensory cells, muscle, and gland cells comprise the major cellular component of modern cnidarians [90]. Cell differentiation is also more sophisticated. For example, the box jellyfish Tripedalia cystophora's sensory clubs (rhopalia) are equipped with statocysts, two lens eyes, and two pairs of simpler pit and slit eyes [91]. Bilaterians show even greater symbiogenic diversification (i.e., head ectoderm taking on mesodermal qualities [the epithelial to mesenchymal transition] and mesoderm taking on epithelial qualities [the mesenchymal to epithelial transition]) [90].

For Katja Seipel and Volker Schmid, however, "it appears that the most parsimonious hypothesis taking into account the recent molecular, cellular, and developmental data is based on a motile life form with mesodermate-like development as a common ancestor of Ctenophora, Cnidaria, and Bilateria" [92]. This "mesodermate hypothesis" proposes "a motile tri-layered cnidarian ancestor and a monophyletic descent of striated muscle in Cnidaria and Bilateria. As a consequence, diploblasty evolved secondarily in cnidarian larvae and polyps" [92].

However neatly the mesodermate hypothesis accounts for the origin and broad occurrence of muscle, the hypothesis raises another problem: Whatever happened to Cnidaria that limited its evolutionary potential to two subphyla plus Myxozoa (of whatever status) in contrast to the proliferation of bilaterian stocks? Conceivably, Placozoa and Ctenophora were limited in their potential by relatively sparse amoebic cells, but cnidarians did not suffer a similar disadvantage. Could it be that Cnidaria's stunted evolution is grounded in their amoebic cells having uniquely acquired cnidocysts?

\section{Acquiring Cnidocysts}

Assuming that the absence of cnidocyts in fossils of scyphozoan-like medusas appearing in the Vendian biota $[81,93,94]$ is not due to taphonomy and diagenesis but genuinely to the absence of cnidocyts, one assumes that a cnidarian/myxozoan branching occurred somewhere between six hundred and four hundred fifty million years ago. Thus, cnidarian origins presumably occurred in the preCambrian prior to if not simultaneous with the origins of bilaterians.

A consensus view of these radiations of metazoans remains elusive due to problems of sufficient sampling of non-bilaterian taxa and appropriate out group choices. Presently, however, broad taxon sampling of genomes supports the branching of Porifera, Placozoa (each with germ cells), and "eumetazoa" (containing nervous systems: Ctenophora, Cnidaria, and Bilateria) $[95,96]$.

The question of whether Cnidaria branched off stem-eumetazoans or early bilaterians remains problematic, since "genome mining and molecular phylogenetic approaches" demonstrate that "a muscle protein core set, including a Myosin type II Heavy Chain motor protein characteristic of striated muscles in vertebrates (MyHC-st), was already present in unicellular organisms before the origin of multicellular animals" while no "protein correlates with the evolutionary origin of muscle... suggest[ing] that the core contractile apparatus in eumetazoan muscles antedates the origin of the animal kingdom and that lineage-specific innovations underlie muscle evolution in cnidarians and bilaterians." Indeed, "tree topology strongly indicates that the myhc-st and myhc-nm genes had already 
Page 5 of 8

separated in the last common ancestor of all animals and the aforementioned protists, with the latter having later lost myhc-st" [97].

Similarly, "[p]hylogenetic analyses indicate that the MHCIIa / MHCIIb duplication is more ancient than the divergence between extant metazoan lineages." Indeed, "Class II myosins originated in unikonts, i.e., eukaryotes ancestrally bearing a single flagellum or no flagellum, including the amoebozoans, fungi and holozoans (e.g., choanoflagellates and multicellular animals or Metazoa)" [98]. Thus, evidence does not exclude the possibility that the convergence of muscle proteins is traceable to pre-metazoan evolutionary source(s) even in non-muscle proteins.

Occam's razor would seem to shave down the muscle "synapomorphy (shared derived character) of the Eumetazoa (Cnidaria + Ctenophora + Bilateria), together with nerve cells" [98] to postbranching evolution due to mutation, duplication, and selection leading to a convergence in bilaterians. The origins of muscle proteins such as Class II myosins, however, would seem to have predated the branching of cnidarians and other eumetazoans. Indeed, the presumptive evolution of muscle proteins does not exclude the possibility that cnidarian genes present in symbiotic amoebic moved by horizontal gene transfer into the genome of cnidarian symbiont(s).

The analysis of the "composition of venomous and structural proteins forming one of the most sophisticated organelles in the animal kingdom" [99], namely, cnidarian cnidocyst, likewise, favours neither the possibility of evolution within cnidarians nor origins from a foreign source stem genes. Indeed, the "final injected nematocyst payload comprises a mixture of dynamically evolving proteins involved in the development, maturation, maintenance, and discharge of the nematocysts, which is unique to each organism and potentially to each nematocyst type" [100].

Bacteria with a protrusion apparatus would seem excellent candidates for genes encoding cnidocyst precursors. Of course, one can only hypothesize that proto-cnidarian amoebic cells were hosts to histozoic symbiotrophic bacteria equipped with an infectious apparatus.

Imagine infectious prokaryotes losing their virulent edge and becoming adapted to a symbiotic lifestyle within amoebic cells in proto-cnidarians. Ultimately, bacterial genes would have to have moved into the nucleus of amoebic cells thereby establishing the genomic foundation for cnidarian cnidocysts. Subsequently, through intra-organismic competition and selection, cnidoblasts would have evolved with all the variations found among cnidocysts coupled to the unique migratory behaviour to epithelial sites and triggering mechanisms.

Anticipating this possibility, Richard Christen et al. [1] commented, "We should note that the mixing of genetic material between two different organisms was probably not as difficult more [than] a billion years ago than it is now, and that transfection of genetic material still exists between present day symbionts such as a plant and Agrobacterium." The notion of gene transfer and incorporation would seem consistent with the abundance of transposable elements and other evidence of horizontal gene transfer in cnidarians as well as the presence of "non-metazoan genes among cnidarian ESTs [expressed sequence tags]" [101]. Indeed, "a flip gene [has] entered a medusozoan genome from the genome of a unicellular organism... in the lineage that gives rise to the germ line (i.e., the interstitial cell lineage)" [102].
Several features of cnidarians relationships with bacteria may be relevant here. First, not surprisingly, like other animals, cnidarians bear their quota of epithelial-bound, stably colonizing microbial communities of various phylotypes [28,103]. Indeed, "microscopic analysis... revealed numerous bacteria within all epithelial cells in all Hydra oligactis polyps analysed irrespective of whether the animals were taken from the long-term laboratory culture $(n=15)$ or directly from the wild $(\mathrm{n}=5)$ " [71], and some "[n]on-metazoan genes among cnidarian ESTs... are candidates for horizontal gene transfer [HGT]" [71] including "seventy-one Hydra gene models show[ing] closer relationships to bacterial genes than to metazoan genes based on sequence similarities and phylogenetic analysis" [71]. Another "90 transposable elements... were potentially horizontally transferred into the Hydra genome" [71].

What is especially intriguing as well as surprising is that budding in brown hydras (if not in algal-laden green species) ceases when bacterial loss is induced experimentally. On the other hand, budding is restored when the bacteria are re-introduced [104]. This intimacy of bacterial symbiosis to cnidarian sexual reproduction would seem to implicate bacteria in cnidarian evolution albeit not necessarily as the source of cnidocytsts.

Finally, the notion of cnidarian amoebic cells having been infected and subsequently colonized by bacterial genes raises the possibility that despite their wealth of amoebic cells, proto-cnidarians did not undergo evolutionary ramifications along the lines of bilaterians or evolve a central nervous system and complex organ systems (beyond gonads, gullet, mesenteries, canals., medusoic statocysts and rhopalia) because the production of cnidocyts preempted cnidarian evolution and diverted it largely toward the elaboration of opportunistic hunters in the mold of polyps, medusas, and parasites.

\section{Summary and Conclusions}

Cnidaria and Myxozoa are linked by molecular, morphological, and developmental homologies begging for a phylogenetic explanation. Microsporidians are not sufficiently homologous to Cnidaria to account for cnidocysts, and Myxozoa bearing cnidocytsts in the form of polar capsules arose from Cnidaria and could not have given rise to cnidarian cnidocyts. Rather, Ediacaran precursors are imagined to have accumulated amoeba-like cells within epithelial-like shells and evolved in several directions. In contrast to metazoans acquiring mesoderm, germ layers, and bilateral symmetry, cnidocyst-less cnidarians may have acquired cnidocysts from infectious bacteria equipped with an extrusion apparatus. Bacterial genes subsequently may have moved to the cnidarian genome programming amoebic cells for cnidocyst production. The branching of Cnidaria from bilaterians, thus, may have been due to cnidarians specializing in cnidocyst evolution while failing to elaborate the complex organs characteristic of bilaterians.

\section{References}

1. Christen R, Ratto A, Baroin A, Perasso R, Grell KB, et al. (1991) Origin of metazoans: A phylogeny deduced from sequences of the $28 \mathrm{~S}$ ribosomal RNA , In: The Early Evolution of Metazoa and the Significance of Problematic Taxa, Alberto M Simonetta and Simon Conway Morris (eds.,) Cambridge University Press, New York.

2. Margulis L, Fester R (1991) Bellagio conference and book. Symbiosis as Source of Evolutionary Innovation: Speciation and Morphogenesis. Conference--June 25-30, 1989, Bellagio Conference Centre, Italy. Symbiosis 11: 93-101. 
3. Sapp J (2010) Saltational symbiosis. Theory Biosci 129: 125-133.

4. Weill R (1934) Contribution a létude des Cnidaires et de leurs nématocytes, Recherches sur les nématocytes (morphologie physiologie - développement), Valeur taxonomique du cnidome. Trav. Station Zoologique de Wimereux, Tome X-XI.

5. Werner B (1965) Die Nesselkapseln der Cnidaria, mit besonderer Berücksichtigung der Hydroida. I. Klassification und Bedeutung für die Systematik und Evolution. Helgoländer wiss. Meeresunters 12: 1-39.

6. Chatton E (1938) "Recherches taxonomiques et cytologiqques sur les Dinoflagellés libres du genre Polykrikos, Butschli leurs cnidocystes et la cnidogénèse." In: Traites et Travaux scientifiques (1906-1937), Imprimerie E. Sottano, Se 'te.

7. Hovasse R (1951) Contribution a l'etude de la cnidogésèse chez les péridiniens. I. Cnidogése cyclique chez Polykrikos schwartzi Butschli. Archiv Zoologische Experimentale Genetik 87: 299-344.

8. Westfall JA, Bradbury PC, Townsend JW (1983) Ultrastructure of the dinoflagellate Polykrikos. I. Development of the nematocyst-taeniocys complex and morphology of the site for extrusion. J Cell Sci 63: 245-261.

9. Gibson SC, Lom J, Pecková H, Ferris VR, Hamilton PB (2005) Phylogenetic analysis of freshwater fish trypanosomes from Europe using ssu rRNA gene sequences and random amplification of polymorphic DNA. Parasitol 130: 405-412.

10. How AT, Bass D, Vickerman K, Chao EE, Cavalier Smith T (2009) Phylogeny, taxonomy, and astounding genetic diversity of glissomonadida ord. nov, the dominant gliding zooflagellates in soil (Protozoa: Cercozoa). Protist 160: 159-189.

11. Vinkerman K, Brugerolle G, Mignot JP (1991) Mastigophora, In: Microscopic Anatomy of Invertebrates, FW Harrison and JA Westfall (eds.) Wiley-Liss, New York.

12. Perkins FO (1991) "Sporozoa": Apicomplexa, Microsporidia, Haplosporidia, Paramyxea, Myxosporidia and Actinosporida, In Microscopic Anatomy of Invertebrates, FW Harrison and JO Corliss (eds.,) Wiley-Liss, New York.

13. Wolf K, Markiw ME (1984) Biology contravenes taxonomy in the Myxozoa: New discoveries show alternation of invertebrate and vertebrate hosts. Science 225: 1449-1452.

14. Nesnidal MP, Helmkampf M, Bruchhaus I, El-Matbouli M, Hausdorf B (2013) Agent of whirling disease meets orphan worm: phylogenomic analyses firmly place Myxozoa in Cnidaria. PLoS One 8: e54576.

15. Schlegel M, Lom J, Stechmann A, Bernhard D, Leipe D, et al. (1996) Phylogenetic analysis of complete small subunit ribosomal RNA coding region of Myxidium lieberkuehni: Evidence that Myxozoa are Metazoa and related to the Bilateria. Arch Protistenkd 147: 1-9.

16. Holland JW, Okamura B, Hartikainen H, Secombes CJ (2011) A novel minicollagen gene links cnidarians and myxozoans. Proc Biol Sci 278: 546-553.

17. Shpirer E, Chang ES, Diamant A, Rubinstein N, Cartwright P, et al. (2014) Diversity and evolution of myxozoan minicollagens and nematogalectins. BMC Evol Biol 14: 205.

18. RaÄkova EV (2005) Cytomorphological characteristics of Polypodium hydriforme and problems of myxozoan and cnidarian phylogeny. Tsitologiia 47: 933-939.

19. Evans NM, Holder MT, Barbeitos MS, Okamura B, Cartwright P (2010) The phylogenetic position of Myxozoa: Exploring conflicting signals in phylogenomic and ribosomal data sets. Mol Biol Evol 27: 2733-2746.

20. Lom J (1990). Phylum Myxozoa, pp. 36-52 in Handbook of Protoctista, L Margulis, JO Corliss, M Melkonian, and DJ Chapman (eds.,) Jones and Bartlett, Boston

21. Tardent $\mathrm{P}$ (1990) Correspondence. Personal communication.

22. Shostak S (1993) A symbiogenetic theory for the origins of cnidocysts in Cnidaria. Biosystems 29: 49-58.

23. Buss LW, Seilacher A (1994) The phylum Vendobionta: a sister group of the Eumetazoa? Paleobiology 20: 1-4.

24. Weidner E, Findley A (2002) Peroxisomal catalase in extrusion apparatus posterior vacuole of microsporidian spores. Biol Bull 203: 212.
25. Foox J, Siddall ME (2015) The Road To Cnidaria: History of Phylogeny of the Myxozoa. J Parasitol 101: 269-274.

26. Monteiro AS, Okamura B, Holland PW (2002) Orphan worm finds a home: Buddenbrockia is a myxozoan. Mol Biol Evol 19: 968-971.

27. Jiménez-Guri E, Philippe H, Okamura B, Holland PW (2007) Buddenbrockia is a cnidarian worm. Science 317: 116-118.

28. Gruhl A, Okamura B (2012) Development and myogenesis of the vermiform Buddenbrockia (Myxozoa) and implications for cnidarian body plan evolution. Evodevo 3: 10.

29. Hyman LH (1940) The Invertebrates: Protozoa through Ctenophora. McGraw-Hill, New York.

30. Ozbek S (2011) The cnidarian nematocyst: a miniature extracellular matrix within a secretory vesicle. Protoplasma 248: 635-640.

31. Feng JM, Xiong J, Zhang JY, Yang YL, Yao B, et al. (2014) New phylogenomic and comparative analyses provide corroborating evidence that Myxozoa is Cnidaria. Mol Phylogenet Evol 81: 10-18.

32. Wainright PO, Hinkle G, Sogin ML, Stickel SK (1993) Monophyletic origins of the metazoa: An evolutionary link with fungi. Science 260: 340-342.

33. Smothers JF, von Dohlen CD, Smith LH Jr, Spall RD (1994) Molecular evidence that the myxozoan protists are metazoans. Science 265: 1719-1721.

34. Kent ML, Margolis L, Corliss JO (1994). The demise of a class of protists: Taxonomic and nomenclatural revisions proposed for the protest phylum Myxozoa Grassé, 1970. Canad J Zool 72: 932-937.

35. Siddall ME, Martin DS, Bridge D, Desser SS, Cone DK (1995) The demise of a phylum of protists: Phylogeny of Myxozoa and other parasitic cnidaria. J Parasitol 81: 961-967.

36. Torres-Machorro AL, Hernández R, Cevallos AM, López-Villaseñor I (2010) Ribosomal RNA genes in eukaryotic microorganisms: witnesses of phylogeny? FEMS Microbiol Rev 34: 59-86.

37. Cavalier Smith T, Chao EE (1996) Molecular phylogeny of the free-living archezoan Trepomonas agilis and the nature of the first eukaryote. J Mol Evol 43: 551-562.

38. Schierwater B, Eitel M, Jakob W, Osigus HJ, Hadrys H, et al. (2009) Concatenated analysis sheds light on early metazoan evolution and fuels a modern "urmetazoon" hypothesis. PLoS Biol 7: e20.

39. Mallatt J, Winchell CJ (2002) Testing the new animal phylogeny: First use of combined large-subunit and small-subunit rRNA gene sequences to classify the protostomes. Mol Biol Evol 19: 289-301.

40. Dyková I, Tyml T, Fiala I, Lom J (2007) New data on Soricimyxum fegati (Myxozoa) including analysis of its phylogenetic position inferred from the SSU rRNA gene sequence. Folia Parasitol (Praha) 54: 272-276.

41. Osigus HJ, Eitel M, Schierwater B (2013) Chasing the urmetazoon: Striking a blow for quality data? Mol Phylogenet Evol 66: 551-557.

42. Canning EU, Okamura B (2004) Biodiversity and evolution of the Myxozoa. Adv Parasitol 56: 43-131.

43. Anderson PA, Bouchard C (2009) The regulation of cnidocyte discharge. Toxicon 54: 1046-1053.

44. Fiala, Ivan. 2008. Myxozoa. Version 10 July 2008 (under construction). http://tolweb.org/Myxozoa/2460/2008.07.10 in The Tree of Life Web Project, http://tolweb.org/.

45. Barto $\AA_{i}$ ov $\tilde{A}_{i}-\operatorname{Sojkov} \tilde{A}_{i}$ P, KodÃ $\tilde{A}_{i}$ dkov $\tilde{A}_{i}$ A, Peckov $\tilde{A}_{i} H$, Kuchta R, Reed CC (2015) Morphology and phylogeny of two new species of Sphaeromyxa Thélohan, 1892 (Cnidaria: Myxozoa) from marine fish (Clinidae and Trachichthyidae). Parasitology 142: 660-674.

46. Stepanjants SD (1988) "Cnidaria origin and the possible way of the Hydrozoa evolution" In: Porifera and Cnidaria, SN Trudor (Ed) Zoology Institute of Academy of Sciences CCCP, Lennigrad.

47. Uspenskaia AV, RaÄkova EV (2001) Cytological aspects of similarity and difference of Myxozoa and Cnidaria. Tsitologiia 43: 284-309.

48. Westfall JA (1966) The differentiation of nematocysts and associated structures in the cnidaria. Z Zellforsch Mikrosk Anat 75: 381-403. 
49. Mariscal RN, Conklin EJ, Bigger CH (1977) The ptychocyst, a major new category of cnida used in tube construction by a cerianthid anemone. Biol Bull 152: 392-405.

50. Tardent P (1988) History and current state of knowledge concerning discharge of Cnidae pp. 309-22 in The Biology of Nematocysts, DM Hessinger and HM Lenhoff (eds.) Academic Press, San Diego.

51. Wood RL (1988) Survey of the ultrastructure of cnidocysts pp. 25-40 in The Biology of Nematocysts, DM Hessinger and HM Lenhoff (eds.) SanDiego: Academic Press.

52. Gershwin LA (2006) Nematocysts of the Cubozoa. Ootaxa 1232: 1-57.

53. Fautin DG (2009) Structural diversity, systematics, and evolution of cnidae. Toxicon 54: 1054-1064.

54. Vervoort W (1966) Skeletal structure in the Solanderiidae and its bearing on hydroid classification pp. 373-96 in The Cnidaria and their Evolution WJ Rees (eds.,), Academic Press, London.

55. Yoffe C, Lotan T, Benayhau Y (2012) A modified view on octocorals: Heteroxenia fuscescens nematocysts are diverse, featuring both an ancestral and a novel type. PLoS One 7: e31902.

56. Picken LER, Skaer RJ (1966) A review of researches on nematocysts pp. 19-50 in The Cnidaria and their Evolution W J Rees (eds.,) Academic Press, London.

57. Shostak S, Kolluri V (1995) Symbiogenetic origins of cnidarian cnidocysts. Symbiosis, 19: 1-29.

58. Schuchert P (2015) World Hydrozoa database.

59. Martin CH (1914) A note on the occurrence of nematocysts and similar structures in the various groups of the animal kingdom. Biologisches Centralblatt 34: 248-273.

60. Lom J (1964) Notes on the extrusion and some other features of myxosporidian spores. Acta Protozoology 2: 321-327.

61. Lom J (1969) Notes on the ultrastructure and sporoblast development in fish parasitizing myxosporidian of the genus Sphaeromyxa. Z Zellforsch Mikrosk Anat 97: 416-437.

62. Shul'man SS (1990) Myxosporidia of the USSR: English Translations Series 75. AA Balkema, Rotterdam.

63. Martin VJ, Thomas MB (1983). Establishment and maintenance of morphological polarity in epithelial planulae. Am Microsc Soc Trans 102: $18-24$.

64. Lentz T L (1966) The Cell Biology of Hydra. North-Holland Publ Co, Amsterdam.

65. Scappaticci AA Jr, Kahn F, Kass Simon G (2010) Nematocyst discharge in Hydra vulgaris: Differential responses of desmonemes and stenoteles to mechanical and chemical stimulation. Comp Biochem Physiol A Mol Integr Physiol 157: 184-191.

66. Zenkert C, Takahashi T, Diesner MO, Özbek S (2011) Morphological and molecular analysis of the Nematostella vectensis cnidom. PLoS One 6: e22725.

67. Watson GM, Mariscal RN (1985) Ultrastructure of nematocyst discharge in catch tentacles of the sea anemone Haliplanella luciae (Cnidaria: Anthozoa). Tissue Cell 17: 199-213.

68. Lyon MK, Kass-Simon G, Hufnagel LA (1982) Ultra structural analysis of nematocyte removal in Hydra. Tissue Cell 14: 415-424.

69. Reft AJ, Westfall JA, Fautin DG (2009) Formation of the apical flaps in nematocysts of sea anemones (cnidaria: actiniaria). Biol Bull 217: 25-34.

70. Bode HR (1996) The interstitial cell lineage of hydra: A stem cell system that arose early in evolution. J Cell Sci 109: 1155-1164.

71. Slautterback DG (1961) Nematocyst development pp. 77-1129 in The Biology of Hydra and of some other Coelenterates HM Lenhoff WF Loomis (eds.,) University of Miami Press, Coral Gables.

72. Chapman JA, Kirkness EF, Simakov O, Hampson SE, Mitros T, et al. (2010) The dynamic genome of Hydra. Nature 464: 592-596.

73. Steele RE, David CN, Technau U (2011) A genomic view of 500 million years of cnidarian evolution. Trends Genet 27: 7-13.

74. Campbell RD (1976) Elimination by Hydra interstitial and nerve cells by means of colchicine. J Cell Sci 21: 1-13.
75. David CN, Murphy S (1977) Characterization of interstitial stem cells in hydra by cloning. Dev Biol 58: 372-383.

76. Martin VJ, Thomas MB (1981) Elimination of the interstitial cells in the planula larva of the marine hydrozoan Pennaria tiarella. J Exp Zool 217: 303-323.

77. Littlefield CL (1985) Germ cells in Hydra oligactis males. I. Isolation of a subpopulation of interstitial cells that is developmentally restricted to sperm production. Dev Biol 112: 185-193.

78. Littefield CL (1991) Cell lineages in Hydra: isolation and characterization of an interstitial stem cell restricted to egg production in Hydra oligactis. Dev Biol 143: 378-388.

79. Martin VJ (1991) Differentiation of the interstitial cell line in hydrozoan planulae: I. Repopulation of epithelial planulae. Hydrobiologigia 216/217:75-82.

80. Chen L, Xiao S, Pang K, Zhou C, Yuan X (2014) Cell differentiation and germ-soma separation in Ediacaran animal embryo-like fossils. Nature 516: 238-241.

81. Liu AG, Matthews JJ, Menon LR, McIlroy D, Brasier MD (2014) Haootia quadriformis n. gen., n. sp., interpreted as a muscular cnidarian impression from the Late Ediacaran period (approx. $560 \mathrm{Ma}$ ). Proc Biol Sci 281.

82. Conway Morris S (2006) Darwin's dilemma: the realities of the Cambrian 'explosion'. Philos Trans R Soc Lond B Biol Sci 361: 1069-1083.

83. Nielsen C (2008) Six major steps in animal evolution: are we derived sponge larvae? Evol Dev 10: 241-257.

84. Grell KG, Ruthmann A (1991) Placozoa, pp. 13-27 in Microscopic Anatomy of Invertebrates FW Harrison and JA Westfall (eds.,) Wiley-Liss, New York.

85. Eitel M, Osigus HJ, DeSalle R, Schierwater B (2013) Global diversity of the Placozoa. PLoS One 8: e57131.

86. Jakob W, Sagasser S, Dellaporta S, Holland P, Kuhn K, et al. (2004) The Trox-2 Hox/ParaHox gene in Trichoplax (Placozoa) marks an epithelial boundary. Dev Genes Evol 214: 170-175.

87. Eitel M, Guidi L, Hadrys H, Balsamo M, Schierwater B (2011) New insights into placozoan sexual reproduction and development. PLoS One 6: e19639.

88. Shostak S (2015) Symbiogeny and the evolution of tissues: The hypothesis. Biol Sys Open Access 4: 1.

89. Bode HR, Flick KM (1976) Distribution and dynamics of nematocyte populations in Hydra attenuata. J Cell Sci 21: 15-34.

90. Technau U, Steele RE (2011) Evolutionary crossroads in developmental biology: Cnidaria. Development 138: 1447-1458.

91. Nilsson DE, Gislén L, Coates MM, Skogh C, Garm A (2005) Advanced optics in a jellyfish eye. Nature 435: 201-205.

92. Seipel K, Schmid V (2005) Evolution of striated muscle: jellyfish and the origin of triploblasty. Dev Biol 282: 14-26.

93. Hagadorn JW, Dott RH, Damrow D (2002) Stranded on a late Cambrian shoreline: Medusae from central Wisconsin. Geology 30: 147-50.

94. Just J, Kristensen RM, Olesen J (2014) Dendrogramma, new genus, with two new non-bilaterian species from the marine bathyal of southeastern Australia (Animalia, Metazoa incertae sedis)--with similarities to some medusoids from the Precambrian Ediacara. PLoS One 9: e102976.

95. Philippe H, Derelle R, Lopez P, Pick K, Borchiellini C, et al. (2009) Phylogenomics revives traditional views on deep animal relationships. Curr Biol 19: 706-712.

96. Pick KS, Philippe H, Schreiber F, Erpenbeck D, Jackson DJ, et al. (2010) Improved phylogenomic taxon sampling noticeably affects nonbilaterian relationships. Mol Biol Evol 27: 1983-1987.

97. Steinmetz PR, Kraus JE, Larroux C, Hammel JU, Amon-Hassenzahl A, et al. (2012) Independent evolution of striated muscles in cnidarians and bilaterians. Nature 487: 231-234.

98. Dayraud C, Alié A, Jager M, Chang P, Le Guyader H, et al. (2012) Independent specialisation of myosin II paralogues in muscle vs. nonmuscle functions during early animal evolution: A ctenophore perspective. BMC Evol Biol 12: 107. 
99. Balasubramanian PG, Beckmann A, Warnken U, Schnölzer M, Schüler A, et al. (2012) Proteome of Hydra nematocyst. J Biol Chem 287: 9672-9681.

100. Rachamim T, Morgenstern D, Aharonovich D, Brekhman V, Lotan T, et al. (2015) The dynamically evolving nematocyst content of an anthozoan, a scyphozoan, and a hydrozoan. Mol Biol Evol 32: 740-753.

101. Technau U, Rudd S, Maxwell P, Gordon PM, Saina M, et al. (2005) Maintenance of ancestral complexity and non-metazoan genes in two basal cnidarians. Trends Genet 21: 633-639.

102. Dana CE, Glauber KM, Chan TA, Bridge DM, Steele RE (2012) Incorporation of a horizontally transferred gene into an operon during cnidarian evolution. PLoS ONE 7: e31643.
103. Putnam NH, Srivastava M, Hellsten U, Dirks B, Chapman J, et al. (2007) Sea anemone genome reveals ancestral eumetazoan gene repertoire and genomic organization. Science 317: 86-94.

104. Fraune S, Bosch TC (2007) Long-term maintenance of species-specific bacterial microbiota in the basal metazoan Hydra. Proc Natl Acad Sci USA 104: 13146-13151. 